\title{
The Center
}

A LOOK AT THE CENTENNIAL CENTER FOR

lowship competitions, language training, public events, and the dissemination of scholarly publications. They are nongovernmental institutions viewed as an official arm of US higher education in the countries in which they are located.

Approximately 400 US educational institutions in 47 states hold roughly 1 ,ooo institutional memberships in the Centers. The organizations play a significant role in facilitating travel for American scholars in countries that are often dangerous and inaccessible. A prominent example is the role that the American Institute of Iranian Studies plays in linking two nations that have no formal diplomatic relations. The Institute provides funding for Iranian scholars to attend conferences in the US and offers grants for US citizens to receive Persian language training in Tehran and conduct research in the country.

Leonardo Villalón (department of political science, University of Florida), Treasurer of the Council of American Overseas Research Centers (the private federation that oversees the Centers) and President of the West Africa Research Association (an AORC with a base in Senegal known as WARC) from 2001-2005, says "the loss of the Department of Education Title VI money for the Centers is a terrible blow to American scholarship on international issues, and an infinitesimally small drop in the bucket in terms of deficit reduction." Villalón believes "there is no single institution that has collectively done more to support American scholars" in West Africa than WARA. He adds that the "support that centers like WARC give scholars in terms of contacts and introductions... as well as logistical support for setting up research, identifying research assistants, [and] securing permits...is invaluable in contributing to efficient and productive research."

The members of the Council of American Overseas Research Centers are the American Academy in Rome, American Center for Mongolian Studies, American Center of Oriental Research, W.F. Albright Institute of Archaeological Research, American Institute of Afghanistan Studies , American Institute of Bangladesh Studies, American Institute of Iranian Studies, American Institute of Indian Studies, American Institute for Maghrib Studies, American Institute of Pakistan Studies, American Institute of Sri Lankan Studies, American Institute for Yemeni Studies, American Research Center in Egypt, American Research Center in Sofia, American Research Institute in Turkey, American School ofClassical Studies at Athens, Cyprus American Archaeological Research Institute, Center for Khmer Studies, Mexico-North Research Network, Palestinian American Research Center, The American Academic Research Institute in Iraq, West African Research Association, American Research Center in Egypt, American Research Center in Sofia, American Research Institute in Turkey, American School of Classical Studies at Athens, Cyprus American Archaeological Research Institute, Center for Khmer Studies, Mexico-North Research Network, Palestinian American Research Center, The American Academic Research Institute in Iraq, and West African Research Association..

\section{POLITICAL SCIENCE \& PUBLIC AFFAIRS}

T he Centennial Center for Political Science and Public Affairs is an invaluable resource to political and social scientists. Since its opening in September 2003, the Center has housed more than 100 scholars. The center, located in the APSA headquarters near Dupont Circle, provides a great base of operations for scholars researching in the DC metro area. The Center offers visiting scholars furnished work space, telephone, fax, computers, Internet access, conference space, a reference library, and access to George Washington University's Gelman Library. Visiting scholar stays range from a few days to 12 months. Space is limited to APSA members and is available for faculty members, postdoctoral fellows, and advanced graduate students from the United States and abroad. Scholars are expected to cover their own expenses and a modest facilities fee for the use of the center. Prospective visiting scholars may apply at any time. Positions are awarded on a space-available basis.

As federal funding sources that support international research continue to diminish ( see Washington Insider, this issue), the Association would like to remind members that the Centennial Center endowed funds provide modest resources for international projects in addition to support for domestic travel and office space at APSA's Washington, DC headquarters (all applicants should note that APSA does not provide support for visa arrangements).

The Center has recently allocated funds for projects in Latin America (Shannon Walsh, University of Notre Dame, "Engendering State Institutions: State Response to Violence Against Women in Latin America") and West Africa (Jamie Bleck, University of Notre Dame, "Can Local Radio Emancipate Rural Women to Become Democratic Agents?). Bleck was awarded her $\mathrm{PhD}$ this year and Walsh is a graduate student. As APSA does not have the resources to replicate the important work of Title VI and Fulbright-Hays, the funds are not intended to be the sole source of support needed to underwrite extensive research abroad. Rather, they are meant to provide critical supplemental assistance for emerging scholars who may not have the history of external funding necessary to competitively solicit grants from major donors.

Interested members can find an application form and more information on the 7 funds that support non-residential scholars at:

http://www.apsanet.org/imgtest/ApplicationNonResident.pdf

Full details on the center and the Visiting Scholars Program are online at http://www.apsanet.org/centennialcenter. You may also contact Veronica Jones at APSA: (202) 483-2512; vjones@apsanet.org. 